\title{
KINERJA BIDANG PARIWISATA DALAM PENGEMBANGAN DESTINASI DAN INDUSTRI PARIWISATA PADA DINAS KEBUDAYAAN, PARIWISATA, PEMUDA DAN OLAHRAGA KABUPATEN KATINGAN
}

\author{
The Performance of Tourism in the Destination and Tourism Industry Development \\ in the Culture, Tourism, Youth and Sports Service of Katingan Regency
}

\section{Sabirin Muhtar* \\ Muhammad Iqbal Nawawi}

Universitas Muhammadiyah

Palangkaraya, Palangka Raya, Central

Kalimantan, Indonesia

email:

sabirin.muhtar@umpalangkaraya.ac.id

\section{Kata Kunci: \\ Kinerja \\ Pengembangan \\ Destinasi \\ Pariwisata \\ Keywords: \\ Performance \\ Development \\ Destination \\ Tourism}

\section{Accepted}

June 2016

\section{Published}

Oktober 2016

\begin{abstract}
Abstrak
Penelitian ini bertujuan untuk memberikan gambaran tentang Kinerja Bidang Pariwisata Dalam Pengembangan Destinasi dan Industri Pariwisata Pada Dinas Kebudayaan, Pariwisata, Pemuda dan Olahraga Kabupaten Katingan. Metode yang digunakan dalam penelitian ini adalah deskriftif kualitatif. Dimana teknik pengumpulan data dengan observasi, wawancara dan dokumentasi. Analisis data menggunakan prosedur analisis data kualitatif, yaitu penggalian makna, penggambaran, penjelasan dan penempatan data konteksnya masing-masing.
\end{abstract}

Hasil penelitian menunjukan dalam penelitian ini adalah Kinerja Bidang Pariwisata Dalam Pengembangan Destinasi dan Industri Pariwisata Pada Dinas Kebudayaan, Pariwisata, Pemuda dan Olahraga Kabupaten Katingan bisa dikatakan baik. Namun perlunya peran serta masyarakat dalam pengembangan pariwisata dan harus di sinergikannya program-program pemerintah dengan instansi terkait itu akan menjadi lebih baik lagi dalam pengembangan pariwisata di Kabupaten Katingan, karena mengingat pariwisata di Kabupaten Katingan ini masih virgin atau masih alami dengan objek-objek yang berupa danau, pegunungan, sungai, bebatuan dan yang lainnya yang masih alami.

\begin{abstract}
This study aims to provide an overview of the Performance of the Tourism Sector in Destination and Tourism Industry Development at the Katingan Regency Culture, Tourism, Youth and Sports Agency. The method used in this study is descriptive qualitative. Where is the technique of collecting data by observation, interviews, and documentation. Data analysis uses qualitative data analysis procedures, namely extracting meaning, drawing, explaining and placing data on their respective contexts.

The results of the research show in this research are the Performance of Tourism in Destination and Tourism Industry Development at the Katingan Regency Office of Culture, Tourism, Youth and Sports. But the need for community participation in tourism development and the synergy of government programs and related institutions will be even better in developing tourism in Katingan Regency, because considering tourism in Katingan Regency is still virgin or still natural with objects in the form of lakes, mountains, rivers, rocks and others that are still natural.
\end{abstract}

\section{PENDAHULUAN}

Pariwisata merupakan salah satu bagian yang tidak dapat terpisahkan dari pembangunan negara, karena pariwisata merupakan salah satu sumber devisa negara yang mempunyai andil besar dalam membangun perokonomian yang dalam suatu negara. Pembangunan sektor pariwisata yang dilakukan dengan baik akan mampu menarik wisatawan domestik maupun wisatawan asing untuk datang dan membelanjakan uangnya dalam kegiatan berwisatanya. Dari transaksi itulah masyarakat daerah wisata akan terangkat taraf hidupnya serta akan mendapat devisa wisatawan asing yang menukar mata uang negaranya dengan rupiah.

Kalimantan Tengah juga memiliki daerah-daerah yang berpotensi memiliki obejk-objek wista kaya akan alam, budaya, kesenian serta taman buatan, salah satu daerah yang memiliki potensi pariwisata tersebut adalah Kabupaten Katingan yang memiliki beberapa objek 
wisata alam yang masih alami dan kental akan budaya dan merupakan salah satu daerah konservasi Borneo kota hijau. Kabupaten Katingan merupakan daerah yang berada di Provinsi Kalimantan Tengah, dan berada 80 km dari lbu kota Provinsi dan juga merupakan daerah lintas Provinsi karena keberadaannya di tengahtengah Provinsi Kalimantan Tengah. Disamping itu, Kabupaten Katingan juga memiliki potensi-potensi wisata alam, serta budaya yang wajib dikunjungi oleh wisatawan domestik maupun wisatawan asing. Ini akan menjadi daya tarik yang ditawarkan bagi wisatawan untuk berkunjung dan mengenal objek-objek wisata di Kabupaten Katingan.

Pada dasarnya pariwisata sangat mengandalkan adanya keunikan, ke khasan, kelokalan, keaslian alam dan budaya yang tumbuh berkembang dalam masyarakat. Pengembangan pariwisata merupakan salah satu cara untuk mewujudkan pariwisata yang maju dan menjadikan salah satu alternatif memperkenlakna suatu daerah. Pengembanagn pariwisata harus dilaksanakan dengan sebaik mungkin dan dengan pengelolaan yang baik pula, berdasarkan hal tersebut diperlukanlah suatu kinerja yang dapat mengelolanya sehingga dapat tercapai pengembangan pariwisata yang diinginkan. Seperti yang diketahui bahwa Kabupaten Katingan merupakan daerah yang banyak memiliki potensipotensi pariwisata, dan pariwisata di Kabupaten Katingan itu sendiri banyak terdapat objek-objek wisata yang cukup menarik dan memiliki potensi untuk dikembangkan menjadi objek wisata yang dapat dijadikan pemasukan daerah.

Indonesia adalah surganya dunia, mengapa demikian, karena Indonesia banyak memiliki tempat-tempat wisata yang menarik, dan menawarkan sejuta keindahan yang akan membuat anda menikmatinya sebagai sebuah pengalaman yang takkan terlupakan, dan pariwisata merupakan aktivitas, pelayanan dan produk hasil industri pariwisata yang mampu menciptakan pengalaman perjalanan bagi wisatawan. Peningkatan kesadaran dan pariwisata masyarakat melalui usaha penyuluhan dan pembinaan kelompokkelompok seni budaya, industri kerajinan, memperkenalkan dan mengembangkan budaya bangsa, terpeliharanya kepribadian bangsa, dan kelestarian lingkungan.

Dalam hal ini kinerja menjadi sorotan publik, karena timbulnya iklim demokratisasi dan keterbukaan. Hal ini tidak mengherankan karena pada dasarnya pelayanan publik menjadi tanggungjawab pemerintah. Dengan demikian, ukuran kinerja pemerintah dapat dilihat dari kinerjanya dalam menyelenggarakan pelayanan publik. Pemerintah bukan hanya sebagai abdi negara, melainkan juga sebagai abdi masyarakat yang mengayomi dan memberikan kenyamanan serta hiburan kepada masyarakat. Pendapat lain dikemukakan poerwadarminta mengemukakan bahwa kinerja adalah prestasi kerja yang diperlihatkan atau kemampuan kerja. Inti pendapat tersebut dapat disimpulkan bahwa kinerja adalah prestasi kerja atau kemampuan kerja yang dihasilkan yang ditujukkan seseorng maupun kelompok orang dalam organisasi dalam mencapai tujuan yang telah ditentukan sebelumnya.

Sedangkan Prasetyo (200I:I) mengemukakan bahwa kinerja atau Performance adalah hasil kerja, sebuah proses manajemen atau organisasi secara keseluruhan, dimana hasil kerja tersebut harus dapat ditunjukkan buktinya secara konkrit dan dapat diukur dengan standar tolak ukur yang telah ditentukan.Menurut Dwiyanto (Pasolong, 2010:244) menjelaskan beberapa indikator yang digunakan untuk mengukur kinerja birokrasi publik, yaitu : Produktivitas, adalah rasio antar input dan output. Secara filosofis produktivitas merupakan sikap mental yang selalu berusaha dan mempunyai pandangan bahwa mutu kehidupan hari ini harus lebih baik dari hari kemarin.

I. Kualitas Pelayanan, merupakan indikator yang relatif tinggi, maka bisa menjadi satu ukuran kinerja birokrasi publik yang mudah dan murah 
digunakan. Kepuasan masyarakat bisa menjadi indikator untuk menilai kinerja birokrasi publik.

2. Responsivitas, yaitu kemampuan birokrasi untuk mengenal kebutuhan masyarakat, menyusun agenda dan priorotas pelayanan, dan mengembangkan program pelayanan publik sesuai dengan kebutuhan masyarakat dan aspirasi masyarakat.

3. Responsibilats, menjelaskan apakah pelaksanaan kegiatan birokrasi publik itu sesuai dengan prinsip administrasi yang benar dengan kebijakan birokrasi baik yang eksplisit dan implisit.

4. Akuntabilitas, menunjuk seberapa besar kebijakan dan kegiatan birokrasi publik tunduk pada para penjabat politik yang dipilih oleh rakyat. Asumsinya, para penjabat politik tersebut karena dipilih oleh rakyat, dengan sendirinya harus memprioritaskan kepentingan publik.

Penulis tertarik untuk meneliti kinerja Bidang Pariwisata pada Dinas Kebudayaan, Pariwisata, Pemuda dan Olahraga Kabupaten Katingan dan ingin lebih mengetahui secara rinci bagaimana kinerja Bidang Pariwisata dalam Pengembangan Pariwisata selama ini, apakah sudah secara optimal atau belum.Dengan kata lain, pengukuran kinerja adalah metode untuk menilai kemajuan/hasil yang telah dicapai untuk dibandingkan dengan tujuan yang telah ditetapkan.

\section{METODOLOGI}

Dalam penelitian ini penulis menggunakan metode penelitian deskriftif kualitatif. Sebagaimana diungkapkan oleh Bogdan dan Biklen (Emzir, 2010:3) penelitian akan menggunakan metode deskritif kualitatif adalah data yang dikumpulkan lebih mengambil bentuk kata- kata atau gambaran dari pada angka-angka. Hasil penelitian tertulis berisi kutipan-kutipan dari data untuk mengilustrasilkan dan menyediakan bukti presentrasi.

\section{HASIL DAN PEMBAHASAN}

Dalam penelitian ini, penulis menemukan hasil penelitian dengan menyimpulkan dari hasil observasi, wawancara, dan dokumentasi yang mana sesuai dengan indikator-indikator yang ada:

a. Produktivitas

Program atau kegiatan yang sudah dilaksanakan dan yang dihasilkan sesuai dengan Pengembangan Pariwisata, Pada Dinas Kebudayaan, Pariwisata, Pemuda dan Olahraga khususnya Bidang Pariwisata, dengan memperkenalkan atau mempromosikan objek-obejk wisata yang ada di Kabupaten Katingan ini, dan juga kami pernah melaksanakan kegiatan kepariwisataan seperti pendakian Bukit Raya, Bukit Bulan, dan Wisata Budaya Desa Betung.

Salah satu hasil yang kami capai dari program atau kegiatan pengembangan pariwisata ini adalah meningkatnya jumlah wisatawan baik dari daerah maupun luar daerah, berbagai objekobjek wisata di Kabupaten Katingan mulai ramai dikunjungi. Dalam melaksanakan program atau kegiatan pengembangan pariwisata memang ada beberapa kendala, namun kendala itu tidak terlalu mengganggu dalam pelaksanaan pengembangan pariwisata ini.

Dari indikator ini peneliti menemukan bahwa dalam pelaksanaannya sudah terealisasi dengan baik diantara program yang dilaksanakan serta yang dihasilkan dari program tersebut.

b. Kualitas Layanan

Sarana prasarana yang kami berikan terhadap objek-objek wisata di Kabupaten Katingan sejauh ini sudah sesuai dengan kebutuhan wisata, mulai dari tempat beristirahat para wisatawan, di dalam objek wisata juga terdapat panggung hiburan, ada gajebo, dan masih banyak lagi. Layanan yang kami berikan terhadap para pengunjung sejauh ini tidak ada masalah, kami telah melaksanakan sesuai dengan standar pelayanan, langkah-langkah kami 
tempuh demi kepuasan para pengunjung wisata dengan memberikan pelayanan berupa jasa penerjemah bagi wisatawan asing, menjelaskan asal usul wisata ini bagi para pengunjung yang penasaran, dan juga kami telah menyiapkan beberapa penjaga objek wisata untuk merawat serta menjaga kenyamanan bagi para pengunjung pariwisata.

Dari narasumber lain yaitu masyarakat sekitar serta pengunjung wisata mengatakan bahwa untuk sarana prasarana sudah memadai meskipun ada beberapa objek wisata yang masih sangat sulit akses jalannya dan juga masih belum tersedianya sarana dan prasarananya. Dari hasil wawancara tersebut, penulis menyimpulkan bahwa untuk kualitas pelayanan yang diberikan Bidang Pariwisata dalam Pengembangan Pariwisata melalui sarana prasarana serta fasilitas di objek-objek wisata sudah cukup baik

c. Responsivitas

Responsivitas, dalam penelitian indikator responsivitas ini, peneliti menemukan beberapa hal mengenai pengembangan pariwisata dengan menggunakan indikator responsivitas. Keluhan yang kami jumpai dari Bidang Pariwisata adalah kadang-kadang ada beberapa pengunjung yang mengelukan adanya kerusakan pada objek-objek wisata yang memang malah sengaja dirusak oleh pengunjung itu sendiri seperti mencoret-coret batu pada wisata Bukit Batu, juga mengeluhkan kurangnya akses ketersedian akses jalan menuju wisata yang ada di daerahdaerah.

Dari keluhan tersebut kami memberikan tanggapan seperti menjelaskan kepada para pengunjung wisata bahwa untuk akses jalan sudah kami usahakan bekerja sama dengan pemerintah daerah. Dari beberapa keluhan tersebut, kami melakukan pengawasan terhadap objek-objek wisata melalui pengelola atau penjaga pariwisata yang bertugas merawat serta menjaga objekobjek wisata yang ada di Kabupaten Katingan. Dari hasil wawancara tersebut, penulis menyimpulkan untuk indikator responsivitas dalam pengembangan pariwisata melalui pelaksanaan program yang melibatkan masyarakat serta dalam memberikan tanggapan atas keluhan pengunjung sejauh ini sudah baik.

d. Responsibilitas

Dalam penelitian ini penulis melihat serta menganalisa pengembangan pariwisata melalui indikator responsibilitas, hasil dari wawancara kepada narasumber adalah Program-program yang dilaksanakan atau dijalankan Bidang Pariwisata sudah sesuai dengan tugas pokok dan fungsi Bidang Pariwisata, yaitu dengan mempersiapkan pengembangan pariwisata secara prioritas, melakukan pengawasan kegiatan kepariwisataan, penggalian pengembangan dan pelestarian objek dan daya tarik wisata, dan juga di bantu seksi-seksi yang ada pada Bidang Pariwisata. Bidang Pariwisata dalam melaksanakan pengembangan pariwisata sudah sesuai atau sudah berdasarkan pada aturan yang berlaku pada kepariwisataan yaitu UU No I I Tahun 2010 tentang Cagar Budaya, dan UU No 10 Tahun 2009 tentang Kepariwisataan. Dalam peraturan tersebut memang sudah sesuai dengan pengembangan pariwisata. Dari masyarakat dan pengunjung sendiri sudah merasakan kenyamanan dalam berwisata, keadaan pariwisata di Kabupaten Katingan juga sudah mulai maju dan diminati banyak wisatawan baik dalam daerah maupun luar daerah.

Kesimpulan yang penulis dapatkan dari hasil wawancara indikator responsibilitas adalah sudah berjalannya pengembangan pariwisata sesuai dengan aturan-aturan kepariwisataan serta sesuai dengan tugas pokok dan fungsi Bidang Pariwisata, bisa dikatakan sejauh ini sudah sangat baik. 
e. Akuntabilitas

Akuntabilitas yang peneliti temukan disini adalah Bidang Pariwisata telah mengupayakan pengembangan pariwisata di Kabupaten Katingan ini berjalan dengan baik, dengan melibatkan masyarakat sekitar objekobjek wisata tersebut adalah upaya yang sudah kami lakukan dalam pengembangan pariwisata. Bentuk tanggung jawab kami melaksanakan program atau kegiatan pengembangan pariwisata dengan melaksanakan pengawasan yang lebih untuk masing-masing objek wisata agar tidak lagi dirusak dan juga bentuk tanggung jawab kami adalah dengan melaporkan setiap atau seluruh pelaksanaan kegiatan kepada Kepala Dinas. Kesimpulan yang penulis dapatkan adalah pengembangan pariwisata di Kabupaten Katingan melalui indikator akuntabilitas ini baik.

\section{KESIMPULAN}

Kinerja Bidang Pariwisata Dalam Pengembangan Pariwisata pada Dinas Kebudayaan, Pariwisata, Pemuda dan Olahraga Kabupaten Katingan secara umum dalam pelaksanaannya sudah bisa dikatakan baik. Hambatanhambatan dalam Kinerja Bidang Pariwisata dalam Pengembangan Pariwisata pada Dinas Kebudayaan, Pariwisata, Pemuda dan Olahraga Kabupaten Katingan adalah Kualitas Layanan atau fasilitas-fasilitas baik dari sarana dan prasarana dan juga akses jalannya belum memadai di beberapa objek-objek wisata Kabupaten Katingan.

Terkait dengan adanya hasil penelitian, maka penulis menyarankan beberapa hal yakni Perlunya adanay peran serta Pemerintah Daerah dalam menambah fasilitasfasilitas baik berupa sarana dan prasarana maupun akses jalan yang masih kurang ataupun belum memadai di beberapa objek-objek wisata di Kabupaten Katingan. Serta adanya tanggung jawab dari Pemerintah Daerah maupun Dinas terkait terhadap objek-objek wisata yang belum memiliki fasilitas-fasilitas baik berupa sarana dan prasarana maupun akses jalan yang belum memadai. Agar nantinya Pengembangan Pariwisata di Kabupaten Katingan menjadi lebih baik lagi yang sesuai dengan kebutuhan dan harapan mayarakat sekitar maunpun pengunjung wisata.

\section{REFERENSI}

Afitah, I. 20I5. Prospek Pengembangan Wisata Danau Bulat Di Kabupaten Katingan Kalimantan Tengah. Daun: Jurnal Ilmiah Pertanian Dan Kehutanan, 2(2), I-I3.

Dwiyanto,Agus. 2002. Penilaian kinerja organisasi pelayanan. Yogyakarta: UGM .

Keban, Yeremias T. 2004. Enam Dimensi Strategis Administrasi Publik Konsep, Teori dan Isu, Gava Media. Yogyakarta.

Mahmudi. 20I0. Manajemen Kinerja Sektor Publik, Edisi. kedua. Yogyakarta : Sekolah Tinggi IImu Manajemen YKPN.

Mahsun, M..2006. Pengukuran Kinerja Sektor Publik. Yogyakarta : BPFE.

Mangkunegara, A.A Anwar Prabu. 2005. Evaluasi Kinerja Sumber Daya Manusia. Bandung: Refika Aditama.

Pasolong, Harbani. 2010. Teori Administrasi Publik. Bandung. Alfabeta.

Poerwardaminta, W.J.S. 2000. Kamus Umum Bahasa Indonesia. Jakarta: Balai pustaka

Prasetyo,irawan. 200I. Analisis kinerja: panduan praktis untuk menganalisis kinerja Organisasi, kinerja proses dan kinerja pegawai. Jakarta: LAN.

Sinambela, Poltak dkk. 2006. Reformasi Pelayanan Publik, (Teori, Kebijakan dan Implementasi). Jakarta : PT. Bumi Aksara.

Wibowo. 2014. Manajemen kinerja. Jakarta: PT Rajagrafindo persada. 